\title{
Erdős Tibor kilencvenedik születésnapjára
}

Erdős Tibor kilencvenéves. Alig akarom elhinni, számomra ő mindig ugyanazzal a szilárd logikával érvelő, a közgazdaságtan valódi tudományos elveit valló, az ezt kétségbe vonó marxista környezettől nem zavartatva a dogmákat könyörtelenül üldöző, igazi elméleti közgazdász-tanár marad, mint amiért a Közgáz hallgatójaként, majd - több más, a marxista dogmáktól elszakadni kívánó fiatal oktatóval együtt - tanársegédként lelkesen hallgattuk az előadásait, és vitatkozva követtük a tanításait. ${ }^{1}$

Az 1970-es években az általa kifejlesztett „makroprofit-elmélet” - kiegészülve Erdős Péter „papirosprofit” fogalmával, valamint a Jánossy Ferenccel folytatott magas szintü szakmai vitában kialakult korszerüsödési ráta elméletével - szorosan kapcsolódik a keynesi iskolához tartozó olyan világhírü közgazdászok munkásságához, mint Harrod, Domar, Sollow vagy éppen Kalecki.

1948-ban kezdte meg egyetemi tanulmányait a Magyar Közgazdaságtudományi Egyetemen, ahol 1952-ben szerzett közgazdászdiplomát, majd az egyetem politikai gazdaságtan tanszékének oktatója lett (az egyetemet 1953-ban Marx Károly Közgazdaságtudományi Egyetemmé nevezték át). 1975-ben távozott az egyetemről, és a Magyar Tudományos Akadémia Közgazdaságtudományi Intézetének tudományos tanácsadójaként kezdett el dolgozni, később kutatóprofesszori megbízást kapott. Az intézet keretében kiemelkedően sokat tett a magyar gazdaság fejlesztéséért és a mindenkori gazdaságpolitika tudományos megalapozásáért.

1962-ben védte meg közgazdaság-tudományból kandidátusi értekezését, majd 1972ben akadémiai doktori címet szerzett. Az MTA Közgazdaság-tudományi Bizottságának ma is tagja. 1987-ben választották meg a Magyar Tudományos Akadémia levelező, 1993-ban pedig rendes tagjává. 1990 és 1993 között a Magyar Közgazdasági Társaság elnöke, 1992 és 2000 között a Magyar Nemzeti Bank jegybanktanácsának

\footnotetext{
${ }^{1}$ E tekintetben hadd hivatkozzam Csaba László 2004-ben írt könyvismertetésére, amelyben így fogalmazott: „A magyar közgazdaság-tudomány egyik vitán felül állandóan meghatározó személyisége... Erdős Tibor akadémikus. ...évtizedeken át a közgazdászok nemzedékei - lényegében az egész mai derékhad - tőle tanulta a makroökonómia alapjait, szemléletét és az igényességet." (Csaba [2004] 283. o.)
}

A kézirat első változata 2018. március 12-én érkezett szerkesztőségünkbe.

DOI: http://dx.doi.org/10.18414/KSZ.2018.4.341 
tagja volt. ${ }^{2}$ 1998-ban vonult nyugdíjba. Az életműve azonban itt nem szakadt meg, alkotókedve továbbra is megmaradt: folytatta OTKA-kutatásait, évröl évre újabb és újabb amerikai szakkönyveket dolgozott fel, és rendszeresen publikálta kutatási eredményeit, gazdaságpolitikai ajánlásait. Erről még később lesz szó.

A makroprofit-elmélet azt a - ma már magától értetődőnek tűnő - tételt fogalmazta meg, hogy ha a gazdaság minden nagyobb csoportja (mondjuk a dolgozók, a tőkések és az állam alkotta zárt gazdaságot feltételezve) csoportszinten egy adott évben pontosan annyit költ el, mint amekkorák a bevételei (bérek, profit, adók), akkor a tőkések csoportjának a profitja szükségszerüen egyenlő lesz a tőkések beruházásokra és fogyasztásra fordított reálkiadásaival (lásd például Erdős [1978]). Ez a tétel egészítette ki Erdős Péternek a papírosprofitra vonatkozó fontos állítását (Erdős P. [1976]). Minek tekinthető a tőkések bevételének az a része, amit nem költenek el sem beruházási, sem pedig fogyasztási javakra az adott évben? Az egyes tőkés szempontjából természetesen ez is „profit”, hiszen a vállalkozásai összkiadásainak költségek, adók feletti részét képezi. Ha azonban ennek egy részét vagy akár az egészét nem költi el reáljavakra, hanem például kötvényt vásárol rajta, vagy csak egyszerủen bankszámlán tartja, az el nem költött profit nem növeli a reálprofitot, ezáltal nem is része a bármilyen módon számított GDP-nek sem. Csak egy „papíros”, innen az elnevezés: papírosprofit.

A makroprofittétel ma már kevésbé érdekes következménye a munkaérték-elméletből levezett kizsákmányolásfelfogás megkérdőjelezése volt. A marxista munkaérték-elmélet szerint (nagyon leegyszerüsítve, de talán a lényeget nem érintve) a tőkések értéktöbblete a munkások által előállított termékek összesített értékének az a része, amelyet a tőkések nem fizetnek meg a munkásoknak bér formájában, hanem munka nélkül visszatartanak értéktöbblet formájában. Lényegében ez a profit forrása. A tőkések tehát munka nélkül jutnak ehhez a bevételhez, vagyis kizsákmányolják a munkásokat. A makroprofit-elmélet alapján azonban jól kitűnik, hogy a profit makroszinten számított hányada (profitráta) - elsősorban a „tőkések” beruházási javakra fordított reálkiadásai - a gazdasági növekedés és fejlődés előmozdítója, motorja, és ilyetén módon nem tekinthető a GDP tőkések által munka nélkül visszatartott részének, vagyis kizsákmányolásnak. ${ }^{3}$

Erdős Tibor makroprofittételét kifejtő munkájának a címe és tartalma is utal már arra, hogy a tétel a kizsákmányolásnál sokkal fontosabb témát is érintett, nevezetesen a gazdasági növekedés és a válság kérdésköreit (Erdös [1980]), különösen a fenntartható fejlödés lehetőségeit. Erdős Tibor munkássága ezen a ponton kapcsolódott szorosan Jánossy Ferencnek a gazdasági növekedés trendvonalairól kifejtett elméletéhez. ${ }^{4}$

Jánossy Ferenc a hatvanas években megalkotta híres trendvonalelméletét, és ennek segítségével majdnem egy évtizeddel korábban megjósolta a hetvenes évek nagy világgazdasági visszaesését. Az általa felállított, történelmi hosszúságú idősorok alapján arra a következtetésre jutott, hogy a hosszú távú gazdasági növekedést biztosító termelési tényezők közül az emberi tőkéé a legfontosabb szerep. Jánossy Ferenc az egyes országok második világháború utáni helyreállítási periódusainak vizsgálata alapján

\footnotetext{
${ }^{2}$ Wikipédia, https://hu.wikipedia.org/wiki/Erdős_Tibor\#Életpályája.

${ }^{3}$ Ezt a következtetést nyilván lehetne értékelméleti szempontból is korrektebben megfogalmazni, a lényegen azonban ez nem változtat.

${ }^{4}$ A leginkább kifejlett formájában lásd erről Jánossy [1966], [1975].
} 
azt az akkor nagyon úttörő megállapítást tette, hogy a helyreállítási időszak nem akkor „ér véget, amikor a termelés ismét eléri a háború előtti szintet, hanem csak (...) akkor, amikor a termelés volumene újból megfelel a gazdasági fejlődés trendvonalának" (Jánossy [1975] 19. o.). Utána pedig olyan pályán halad, mintha egyáltalán nem is lett volna háború. Jánossy bevezeti a szakmastruktúra fogalmát, amely „egy ország teljes munkaerő-állományának szakmák szerinti tagozódását jelenti, éspedig aszerint, hogy egy-egy szakmával hányan rendelkeznek" (234. o.). Ez sokkal elvontabb fogalom, mint a jól ismert foglalkozási struktúra. A mai közgazdasági szóhasználattal élve, az elöbbit inkább az „emberi tőke” egy fajtájának tekinthetnénk. ${ }^{5}$

Erdős Tibor a beruházások felől közelítve tette fel a hasonló kérdést: gyorsítható-e hosszú távon a gazdasági növekedés üteme a beruházások arányának növelésével (Erdős [1974]). E sorok szerzője több írásában is foglalkozott a beruházási ráta, a növekedési ütem és a korszerűsödési ráta kérdéseinek összefüggéseivel (Bara [1980] és [1981]). Az akkor publikált írásaimban megállapítottam, hogy a hatvanas évek közepéig a magyar szakirodalomban a „beruházáscentrikus” növekedésfelfogás volt az uralkodó. Lényegében ezt az álláspontot képviselte Erdős Tibor is 1966-ig. Ennek a felfogásnak az volt a lényege, hogy a beruházási ráta nagyobb mértéke - ceteris paribus - magasabb növekedési ütemet eredményez. Jánossy ezzel szemben már ebben az időben is azt tartotta, hogy a termelékenység növekedési üteme hosszabb időszakban lényegében független a beruházási hányad nagyságától, illetve ugyanakkora növekedési ütem elérhető magas és alacsony beruházási hányadokkal egyaránt. Erdős Tibor az 1972-ben megjelent könyvében már úgy fogalmaz, hogy nincs minden körülmények között érvényes összefüggés a beruházási hányad és a növekedési ütem között: hiába újítjuk meg egyre nagyobb hányadban a termelési eszközeinket, ennek önmagában egyre kisebb termelékenységnövelő hatása lesz (Erdős [1972]).

E szemléletváltást követően Erdős Tibor gondolatmenetének középpontjában már nem a beruházási/megújulási ráta állt, hanem a termelés korszerüsödése. A korszerüsödés az újonnan gyártott termelöberendezések termelékenységnövelö hatását, illetve képességét jelenti. Ha a korszerüsödési ráta 1,02, ez azt jelenti, hogy az adott évben legyártott gép 1,02szer, vagyis 2 százalékkal nagyobb termelékenységet tesz lehetővé, mint a megelőző évben legyártott hasonló rendeltetésü gép. A korszerüsödési ráta magas vagy alacsony színvonala azt fejezi ki, hogy a termelőegységek, vállalatok évről évre mennyivel jobb, hatékonyabb termelőberendezéseket, mennyivel korszerübb anyagokat alkalmazhatnak a termelésben, és milyen találmányokat, szabadalmakat vezetnek be (Erdös [1974]).

Erdős Tibor először az 1986-ban publikált könyvében kapcsolta össze a saját korszerüsödésiráta-elméletét Jánossy Ferenc trendvonalelméletével (Erdős [1986]). Itt már a műszaki fejlődéssel azonos értelemben használja a korszerüsödési rátát. A fogalom utal arra, hogy a növekedés dinamikája nem csupán a gépek korszerüsödésétől, hanem egyéb tényezőktől, például a felhasznált anyagok összetételének és minőségének változásától is függ. „A korszerüsödési ráta Jánossy Ferenc »trendvonalával« rokon fogalom. (...) Mindkettő arra hívja fel a figyelmet, hogy a gazdasági növekedés üteme nem gyorsítható fel hosszabb időszakban a beruházási ráta egyszerü megnövelésével.” (Erdős [2000] 103. o.)

\footnotetext{
${ }^{5}$ Lásd erről például Tarján Tamás - Jánossy Ferenc munkásságának elhivatott kutatója - tanulmányát (Tarján [2000]).
} 
Modern viszonyok között a gazdasági növekedés üteme közvetlenül elsősorban a műszaki fejlődés ütemétől függ. Ha ez utóbbi adott, és a beruházási ráta mégis növekvő, akkor a növekedési ütem - eltekintve a munkaerő létszámbővítésének esetétől - csak átmenetileg emelkedhet. Annyiban és addig lehet így a növekedés gyorsabb, amennyiben és amíg a gépek és berendezések átlagos életkora a nagyobb arányú beruházások miatt csökken. Bármilyen nagy arányú is a beruházás, a berendezések átlagos életkorának csökkenése véges, ezért a növekedés tartósan nem gyorsítható pusztán a beruházási ráta megemelésével. A tartósan dinamikus gazdasági növekedés elérése tehát a műszaki fejlődés gyorsulásától, nagyobb sebességétől függ, és természetesen azoktól a tényezőktől, amelyek a gyorsabb müszaki fejlődés hátterében állnak. Ezzel Erdős Tibor korszerüsödésiráta-elmélete elérte azt a szintet, amely után már annak alkalmazásai kerültek előtérbe a rendszerváltást követő évtizedekben.

A transzformációs visszaesést követő növekedést Erdős Tibor szerint nem indokolt a Jánossy-féle helyreállítási periódusként értelmezni. Utóbbi alapjául az emberi tôke - eredetiben a szakmastruktúra - változatlansága szolgált. A munkaerő és főleg annak tudása Magyarországon a kilencvenes években viszont nem volt változatlan. Sőt páratlan átrendeződések jellemezték a számítógépes forradalom, a tulajdonosváltozás, a működőtőke beáramlása, a piacváltás, a mindezekhez történő tömeges alkalmazkodás és/vagy a munkahelyek jelentős százalékának megszűnte következtében. Ez azt jelenti, hogy a modell alapjául szolgáló feltételezések veszítették el érvényüket (Erdős [2003]).

Az elméleti tisztázást követően Erdős Tibor már a rendszerváltást megelőzően is igyekezett áttérni a magyar gazdasági problémák vizsgálatára, a hazai gazdasági szerkezet hiányosságainak, ezek kijavításainak lehetőségeit kutatva. Azzal a kifejezett céllal tért át az infláció, a pénzügyek, a monetáris szabályozás és a hazai gazdasági növekedés kutatására, hogy segítse a gondok megoldásában az éppen aktuális gazdaságpolitikát. Jelen írás terjedelmi korlátai nem engedik meg, hogy ezek tartalmát külön ismertessük az ebben a szellemben és céllal született cikkek témáinak felsorolásán túlmenően. Erdős Tibor írásaiban az adott időszak égető kérdéseire kereste a választ: a kilencvenes években az infláció (Erdős [1998]), majd a 2000-es évek első felében a fenntartható gazdasági növekedés állt kutatásainak középpontjában (Erdös [2000], [2003], [2006b]). Még a válság kitörése előtt a maastrichti követelmények fényében elemzi Magyarország helyzetét (Erdős [2006a], [2006b]), majd a válságkezelés elméleti kérdéseit feszegeti (Erdős [2009]). Végül a 2010-ben hatalomra került Fidesz-kormány adóztatási politikáját veszi górcső alá a hatékonyság és a növekedésre gyakorolt hatásuk szempontjából (Erdős [2012], [2014]).

A fenti írások közös sajátja az Erdős Tiborra jellemző közgazdasági elméleti következetesség és az alkalmazások terén mutatott világos kritikai mondanivaló, ami együtt járt azzal, hogy a gazdaságpolitikai döntéshozók hasonló következetességgel hagyták figyelmen kívül az ajánlásait. Ez sajnos ma már szinte dicséretnek számít, mintsem kritikának. Ez természetesen semmit sem csökkent Erdős Tibor érdemein, annál inkább az érintett döntéshozókén.

Erdős Tibor munkássága elismeréseképpen nagyon sok díjat megkapott, így 2008ban a Magyar Köztársasági Érdemrend középkeresztjét a csillagokkal és a Magyar Közgazdasági Társaság életmüdíját is. 


\section{Hivatkozások}

BARA Zoltán [1980]: Trendvonal és korszerűsödési ráta. Jánossy Ferenc és Erdős Tibor növekedéselméleteinek összehasonlító elemzése. Egyetemi doktori disszertáció. MKKE, Budapest.

BARA ZoLTÁN [1981]: Beruházási ráta, növekedési ütem és korszerűsödés az évjáratmodellben. Egyetemi Szemle, 3. sz.

Csaba LÁszló [2004]: Erdős Tibor: Fenntartható gazdasági növekedés. Könyvismertetés. Közgazdasági Szemle, 51. évf. 3. sz. 283-287. o.

ERDős PÉTER [1976]: Az adóztatás és a profithányad összefüggésének törvényszerüségeiről. Tanulmányok a kapitalizmus politikai gazdaságtanának vitatott kérdéseiről. MTA Közgazdaság-tudományi Intézet, Budapest.

ERDős TiBOR [1972]: Gazdasági növekedés a fejlett tőkésországokban. Kossuth Kiadó, Budapest. ERDős Tiвor [1974]: A termelés korszerüsödése és a gazdasági növekedés. Kossuth Kiadó, Budapest.

ERDős Tiвor [1976]: Erdős Péter: Bér, profit, adóztatás. Szakirodalmi Tájékoztató. Közgazdasági Szemle, 23. évf. 9. sz. 1110-1119. o.

ERdős Tiвor [1978]: The determinants of the magnitude, rate and share of profits on macroeconomic level. MTA Közgazdaság-tudományi Intézet, Budapest, 93 o.

ERDős TiвоR [1980]: Makroszintű profit. Gazdasági növekedés - válság. Kézirat. MKKE Közgazdasági Továbbképző Intézet, Budapest.

ERDős Tiвor [1986]: Növekedési ütem, növekedési pálya. Közgazdasági és Jogi Könyvkiadó, Budapest.

ERDős TiвOR [1998]: Infláció. Különös tekintettel az 1990-es évek magyar gazdaságára. Akadémiai Kiadó, Budapest.

ERDős Tiвor [2000]: A fenntartható növekedés egyensúlyi feltételei - I. Közgazdasági Szemle, 47. évf. 2. sz. 101-115. o.

ERdős Tibor [2003]: Fenntartható gazdasági növekedés. Akadémiai Kiadó, Budapest.

ERDős Tiвor [2006a]: Maastrichti követelmények, adóztatás, növekedési potenciál. MEHNemzeti Fejlesztési Hivatal, Budapest. (Európai műhelytanulmányok.)

ERDős Tiвor [2006b]: Növekedési potenciál és gazdaságpolitika. Akadémiai Kiadó, Budapest. ERdős Tibor [2009]: Válságkezelés Magyarországon - elméleti elemzés. Pénzügyi Szemle, 54. évf. 2-3. sz. 219-257. o.

ERDős TiвоR [2012]: Egykulcsos jövedelemadó és gazdasági növekedés. Közgazdasági Szemle, 59. évf. 2. sz. 109-138. o.

ERDős TiвоR [2014]: Adóztatás, hatékonyság és gazdasági növekedés. Közgazdasági Szemle, 61. évf. 1. sz. 1-26. o.

JánOssy Ferenc [1966]: A gazdasági fejlődés trendvonala és a helyreállítási periódusok. Közgazdasági és Jogi Könyvkiadó, Budapest.

JÁnOssy FERENC [1975]: A gazdasági fejlődés trendvonaláról. Magvető Könyvkiadó, Budapest. TARJán TAmás [2000]: Jánossy elmélete az új növekedési elmélet tükrében. Közgazdasági Szemle, 47. évf. 5. sz. 457-472. o.

Bara Zoltán

Bara Zoltán a Budapesti Corvinus Egyetem professor emeritusa (e-mail: barazoltan100@gmail.com). 